\title{
非金属軸受とその性質
}

\author{
水野 昂一*
}

\section{1. 非金属軸受の特色}

非金属軸受材料として合成樹脂，ゴム，木材，黑鉛， セラミックなどが挙げられる。これらはそれぞれの特性 を活用して軸受として利用されているが，その共通して いる特色として金属合金軸受材料と異なる点は，水潤滑 軸受あるいは無給油軸受として使用できることである。
表 1 ふ各種軸受材料の諸性質をまとめたもので,きわめ て概括的であるが同一単位で比較してみた。軸受合金の 限界 $P V$ 值は油膜潤滑でほ 1000 10000 の数值が得られ ているが，合成樹脂は特に潤滑油を用いても1000以下で あり，水潤滑でも500〜1000である。また無給油軸受

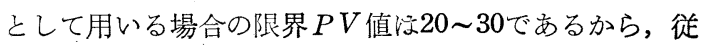
来軸受合金を用いていたところにそのままの設計で合成

表 1 各種軸受材料の諸性質

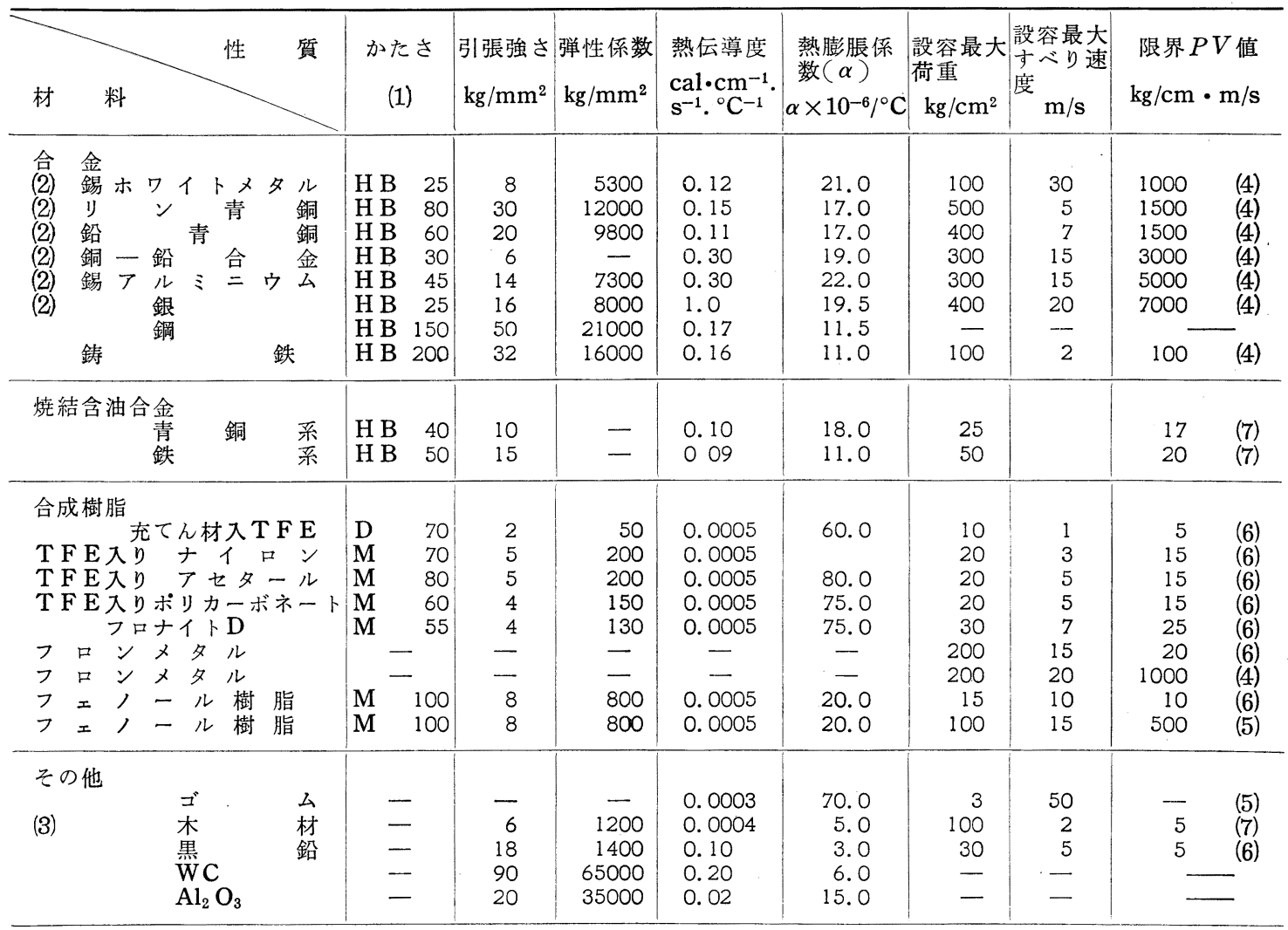

(1) $\mathrm{HB}=\mathrm{BRINEL}$ HARDNESS, $\mathrm{D}=\mathrm{SHORE}$ DUROMETER, $M=$ ROCKWELL $R$

(2) 鋼バックにライニングしたもの

(3) リグナムバイタおよび樫, 楓の含油処理材
(4) 油膜潤滑

(5) 水潤滑

（6）完全無給油

(7) 含油材

*日本バイメタル株式会社 
樹脂を無給油状態で使用することは無理であり，たとえ 給油しても種々の制約が生ずる。しかし現在 $P . V$ 值 20 以 下で油膜潤滑で軸受合金を用いているところは多いので あるから，そのようなところには合成樹脂を適用できる し, むしろ有利である場合が多い。フェノール樹脂軸受, ゴム軸受は水潤滑で合金軸受の及ばない領域で特色を発 揮している。黒鉛軸受ほ無給油軸受, 高温用軸受, 耐食 用軸受 (海水, ガンリン, 酸, アルカリなど) としての 有用性は大きい。 $\mathrm{Al}_{2} \mathrm{O}_{3}$ 注原子力関係機器の軸受として 特色を発揮している。

\section{2. 合成樹脂軸受}

\section{1 ふっそ樹脂}

ふっ素樹脂とほ 2 ふっ化ビニリデン， 3 ふっ化塩化エ チレン (以下 $3 \mathrm{~F}$ と略記する)，4ふっ化ェチレン(以下 $4 \mathrm{~F}$ と略記する), ふっっ化エチレンプロピレン(以下FEP と略記する）などがあり，いずれも一応軸受材料として の適性を有している。しかし 4 F (TF E，テフロン， ポリフロン）以外は一般の熱可塑性樹指と同様に明確な 溶融点を有し, 加工性も良いが，4 Fにはいわゆる融点 はなく, $327^{\circ} \mathrm{C}$ に転移点があって結晶性を失なって無定 形 (ゲル化) になり，400 C 以上で徐々に分解する。 $4 \mathrm{~F}$ の機械的強さほ加熱温度に応じて低下するが, $250^{\circ} \mathrm{C} く ゙$ らいまでほ軸受として役立つ。このように $4 \mathrm{~F}$ は熱に強 く, 摩擦係数は小さく, 非粘着性であり, 化学的に安定 であるため乾燥摩擦用軸受としては他の追随を許さな い。また $4 \mathrm{~F}$ 自身が固体潤滑剂である。4 F の耐摩耗性を改 良するために各種の添加材, 充てん材が使用されるが, これらによって耐摩耗性は良くなっても逆に摩擦係数を 多くして摩擦熱の発生を助長する結果になっている。現 用の軸受材としては充てえ材を添加した $4 \mathrm{~F}$ の成形品と その応用軸受， $4 \mathrm{~F}$ の繊維を織布として加工した繊維軸
受, 鋼材表面に銅合金粉末の焼結層をつけて $4 \mathrm{~F}$ を含浸 被覆した三層材による軸受, $3 \mathrm{~F}$ および F E P の成形品さ らに $4 \mathrm{~F}$ を潤滑材として他種合成樹脂その他に混合した もの，合金焼結体に $4 \mathrm{~F}$ を含浸させたものなどがある。

2. 1. 1 充てん材入り $4 \mathrm{~F}$ 成形品

$4 \mathrm{~F}$ の成形用粉末に各種充てえ材を混合して成形した ものでシート,板, 管, 棒, ブロック材, 積層材などとして 種々の形式の軸受とする。テープライナインサートブシ ニはテープ状の $4 \mathrm{~F}$ 鋼をたほアルミニウムのブシュの 内側あるい軸の外周にはめこんだ形式である。充てん 材によって耐摩耗性のみでなく, クリープ, 強さ, 寸法 安定性が改良される。 $4 \mathrm{~F}$ 自体の摩擦係数注 $0.04 \sim 0.08$ と称されるが，充てえ材入りは $0.1 \sim 0.2$ になる。表 $2^{1}$ 㳘てえ材入りテフロンの $P V$ 值と摩擦特性を示す。使 用可能温度は $-200 \sim+250^{\circ} \mathrm{C} て ゙ あ り$, 特に強酸, 強了 ルカリ，各種溶剤中で用いる軸受としてほ最適である。 しかし $4 \mathrm{~F}$ 成形体の強さ活概して軸受としてほ不十分で ある。また高価でもある。

\section{1.2 繊維軸受 ${ }^{2)}$}

ポリフロン繊維織布を裏金に接着させたもので，接着 性を良くするため, 表面に $4 \mathrm{~F}$ の繊維が出て裏面注綿系 が出るような綿裏打ち外層織布を使用し，フェノール樹 脂を含浸させてハウジングの内面に加熱加圧接着する。 織布自身の機械的強度も増加し, 耐摩耗性ほ著しく改良

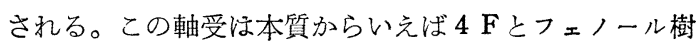
脂との混成体である。高荷重低速用軸受として良好な性 能を示し, $4000 \mathrm{~kg} / \mathrm{cm}^{2}$ の荷重に耐える。もちろん無給油 軸受であり，0 $129^{\circ} \mathrm{C}$ の温度範囲で使用できる。

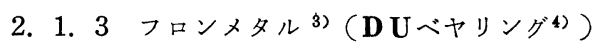

鋼材表面に青銅合金粉末を焼結し,この多孔性粗面に4 $\mathrm{F}$ の被膜を結着させたもので, $4 \mathrm{~F}$ の膜は強固に密着して いるので鋼板を基材とした板材ふ曲げ加工，しぼり加工

表 2 充てん材入りテフロンの $P V$ 值と摩擦特性（乾燥摩擦）

\begin{tabular}{|c|c|c|c|c|c|}
\hline 性 & 単 味 & $\begin{array}{l}\text { 25\%グラス } \\
\text { フォイバ }\end{array}$ & $\begin{array}{l}\text { 60\% } \\
\text { ブロソズ }\end{array}$ & $\begin{array}{c}20 \% \text { グラス } \\
+ \\
5 \% \text { I ラフォイト }\end{array}$ & $\begin{array}{c}15 \% \text { グラス } \\
+\stackrel{ }{+} \\
5 \% \mathrm{MOS}_{2}\end{array}$ \\
\hline $\begin{array}{c}\text { 限界 } P V \text { 值 }\left(\mathrm{kg} / \mathrm{cm}^{2} \cdot \mathrm{m} / \mathrm{min}\right) \\
V=3.05 \mathrm{~m} / \mathrm{min} \\
V=30.5 \mathrm{~m} / \mathrm{min} \\
V=305 \mathrm{~m} / \mathrm{min}\end{array}$ & $\begin{array}{l}26 \\
39 \\
54\end{array}$ & $\begin{array}{l}214 \\
278 \\
340\end{array}$ & $\begin{array}{l}320 \\
396 \\
600 \\
\end{array}$ & $\begin{array}{l}326 \\
320 \\
470 \\
\end{array}$ & $\begin{array}{l}236 \\
300 \\
374 \\
\end{array}$ \\
\hline $\begin{array}{l}\text { 1000時間で } 0.125 \mathrm{~mm} \text { 摩耗す } \\
\text { る場合のPV值 }\end{array}$ & - & 107 & 190 & 70 & 117 \\
\hline $\begin{array}{l}\text { 摩耗係数 } K \times 10^{10} \\
\mathrm{~cm}^{2} \cdot \mathrm{min} / \mathrm{kg} \cdot \mathrm{h}\end{array}$ & 17600 & 12 & 7 & 17.6 & 10.5 \\
\hline 摩 耗 倸 数 * & $\begin{array}{l}0.16 \\
0.12\end{array}$ & $\begin{array}{l}0.18 \\
0.16\end{array}$ & $\begin{array}{l}0.18 \\
0.14\end{array}$ & $\begin{array}{l}0.18 \\
0.16\end{array}$ & $\begin{array}{l}0.16 \\
0.14\end{array}$ \\
\hline
\end{tabular}

* 試験条件 $P=0.14 \mathrm{~kg} / \mathrm{cm}^{2}, V=6.1 \mathrm{~m} / \mathrm{min}$, 温度 $24^{\circ} \mathrm{C}$, 相手硬鋼 
表 3 フロンメタルの乾燥摩擦における $P V$ 值

\begin{tabular}{c|r|c|c|c}
\hline \multirow{2}{*}{$\begin{array}{c}\text { む速度 } V \\
\mathrm{~m} / \mathrm{s}\end{array}$} & \multicolumn{4}{|c}{ 使用環境温度 $\left({ }^{\circ} \mathrm{C}\right)$} \\
\cline { 2 - 5 } & 常 & 温 & 100 & 200 \\
\cline { 2 - 5 }$P \mathrm{~kg} / \mathrm{cm}^{2}$ & $P V$ & $P V$ & $P V$ \\
\hline 0.01以下ときどき摇動 & 500 & 5 & 3 & 1 \\
O.1 & 60 & 6 & 3.5 & 1.2 \\
0.5 & 15 & 7.5 & 4.5 & 1.5 \\
1.0 & 12 & 12 & 7.2 & 2.4 \\
5.0 & 4 & 20 & 12 & 4 \\
10.0 & 2 & 20 & 12 & 4 \\
20.0 & 0.5 & 10 & 9 & 2 \\
\hline
\end{tabular}

が可能で巻ブシュ, 半円形メタル, 球面座軸受その他プ レス加工して種々の軸受製品が得られる。軸受としての 剛性強度は十分あり，寸法变化や軸受すきまの減少など の心配も少ない。 $P V$ 值は乾燥摩擦で $20 \mathrm{~kg} / \mathrm{cm}^{2} \cdot \mathrm{m} / \mathrm{s}$ で あるから合成樹脂の軸受としては最高位に属する。 $P V$ 值注使用環境によって変化するものであり，フロンメタ ルの場合心表 3 に示すように使用環境温度の变化によっ て大きな差を生ずる。 $200^{\circ} \mathrm{C}$ 以上の雾囲気中で使用する 場合はそれだけ $P V$ 值の少ない条件を要する。フロンメ タルを油膜潤滑軸受として使用する場合の $P V$ 值を表 4 に示す。実用的 $P V$ 值ほ 500 以下がよいが，表 1 で示し
表 4 フロンメタルの油膜潤滑における $P V$ 值

\begin{tabular}{c|c|c}
\hline $\begin{array}{c}\text { すべり 速度 } V \\
(\mathrm{~m} / \mathrm{s})\end{array}$ & $\begin{array}{c}\text { 訴 容 荷 重 } P \\
\left(\mathrm{~kg} / \mathrm{cm}^{2}\right)\end{array}$ & $P V$ 值 \\
\hline 0.5 & 300 & 150 \\
1.0 & 300 & 300 \\
5.0 & 250 & 1,250 \\
10.0 & 200 & 2,000 \\
15.0 & 150 & 2,250 \\
\hline
\end{tabular}

たように軸受合金とまったく同様な扱いでよく，焼付に 対して著しく鈍感であることが特長である。

\section{24 Fを潤滑材として添加した合成樹脂}

\section{2. 1 概括}

黑鉛やMo S 2 ほ有用な固体潤滑材であるが，これらを 合成樹脂に添加してあるもの沙摩擦係数を少なくし，あ るもの洏摩耗性を向上するのに効果がある。しかし， 合成樹脂といわゆる性の合わない場合注逆効果を呈す る。これに反して 4 F ほその耐熱性, 化学的不活性のた め現用の合成樹脂に添加して全般的に一応軸受性能が改 良される。これは摩擦係数の減少, 耐熱性の向上などに よるものと考えられる。表 $5^{5)}$ はアセタール，ナイロ ン,ポリカーボネート, ポリウレタン,フェノールの各 樹脂に $4 \mathrm{~F}$ を添加した場合の効果を示すものであり，そ

表 5 $4 \mathrm{~F}$ を潤滑材として添加した各種材料の軸受特性（乾燥摩擦）

\begin{tabular}{|c|c|c|c|c|c|c|c|c|c|}
\hline \multirow{3}{*}{ 材料 } & \multicolumn{2}{|c|}{ 添加材 (Vol\%) } & \multirow{3}{*}{$\left|\begin{array}{c|}\begin{array}{c}\text { 摩耗係数 } \\
K \times 10^{10} \\
\mathrm{~cm}^{2} \cdot \mathrm{min}\end{array} \\
\mathrm{kg} \cdot \mathrm{h}\end{array}\right|$} & \multicolumn{4}{|c|}{ 限 界 $P V$ 值 $\left(\mathrm{kg} / \mathrm{cm}^{2} \cdot \mathrm{m} / \mathrm{min}\right)$} & \multicolumn{2}{|c|}{ 摩 擦 係 数 } \\
\hline & \multirow[b]{2}{*}{$4 \mathrm{~F}$} & \multirow{2}{*}{$\begin{array}{l}\text { ガラ ス } \\
\text { フォイハ }\end{array}$} & & 試 & 験 法 & $\mathrm{A}$ & 試験法 & & 動 \\
\hline & & & & $3.05 \mathrm{~m} / \mathrm{min}$ & $30.5 \mathrm{~m} / \mathrm{min}$ & $305 \mathrm{~m} / \mathrm{mir}$ & B & $2.8 \mathrm{~kg} / \mathrm{cm}^{2}$ & $\begin{array}{c}15 \mathrm{~m} / \mathrm{min} \\
2.8 \mathrm{~kg} / \mathrm{cm}^{2}\end{array}$ \\
\hline アセタールコポリマ & $\begin{array}{r}- \\
5 \\
15 \\
15\end{array}$ & - & $\begin{array}{r}76 \\
47 \\
24 \\
235 \\
\end{array}$ & $\begin{array}{r}64 \\
640 \\
640 \\
200 \\
\end{array}$ & $\begin{array}{r}56 \\
160 \\
200 \\
190 \\
\end{array}$ & $\begin{array}{r}40 \\
48 \\
88 \\
128 \\
\end{array}$ & $\begin{array}{r}48 \\
80 \\
120 \\
80 \\
\end{array}$ & $\begin{array}{l}0.14 \\
0.12 \\
0.07 \\
0.20\end{array}$ & $\begin{array}{l}0.21 \\
0.18 \\
0.15 \\
0.28 \\
\end{array}$ \\
\hline $\begin{array}{lllll}\text { ア } & セ & \text { タ } & \text { ル } \\
\text { ホ } & モ & ホ ゚ & \text { マ }\end{array}$ & $\begin{array}{l}-15 \\
15\end{array}$ & - & $\begin{array}{l}70 \\
26 \\
26 \\
\end{array}$ & $\begin{array}{r}64 \\
640 \\
640 \\
\end{array}$ & $\begin{array}{r}56 \\
200 \\
200 \\
\end{array}$ & $\begin{array}{r}40 \\
160 \\
160 \\
\end{array}$ & $\begin{array}{r}48 \\
128 \\
128 \\
\end{array}$ & $\begin{array}{l}0.11 \\
0.09 \\
0.10 \\
\end{array}$ & $\begin{array}{l}0.22 \\
0.14 \\
0.16\end{array}$ \\
\hline ナイロン 66 & $\begin{array}{l}-15 \\
15\end{array}$ & - & $\begin{array}{r}235 \\
15 \\
18 \\
\end{array}$ & $\begin{array}{r}48 \\
640 \\
280 \\
\end{array}$ & $\begin{array}{r}40 \\
440 \\
320 \\
\end{array}$ & $\begin{array}{r}40 \\
128 \\
210 \\
\end{array}$ & $\begin{array}{r}32 \\
112 \\
160 \\
\end{array}$ & $\begin{array}{l}0.24 \\
010 \\
0.19 \\
\end{array}$ & $\begin{array}{l}0.26 \\
0.18 \\
0.26\end{array}$ \\
\hline ナイロン 6 & $\begin{array}{l}- \\
15 \\
15\end{array}$ & - & $\begin{array}{r}235 \\
18 \\
20 \\
\end{array}$ & $\begin{array}{r}48 \\
640 \\
280\end{array}$ & $\begin{array}{r}40 \\
440 \\
320 \\
\end{array}$ & $\begin{array}{r}40 \\
128 \\
210 \\
\end{array}$ & $\begin{array}{r}32 \\
112 \\
160 \\
\end{array}$ & $\begin{array}{l}0.22 \\
0.09 \\
0.20\end{array}$ & $\begin{array}{l}0.26 \\
0.19 \\
0225\end{array}$ \\
\hline ポリカーボネート & $\begin{array}{l}- \\
15 \\
15\end{array}$ & $\frac{-}{30}$ & $\begin{array}{r}2490 \\
88 \\
35 \\
\end{array}$ & $\begin{array}{r}12 \\
640 \\
440\end{array}$ & $\begin{array}{r}8 \\
320 \\
480 \\
\end{array}$ & $\begin{array}{l}N^{*} \\
170 \\
210 \\
\end{array}$ & $\begin{array}{r}4 \\
112 \\
80 \\
\end{array}$ & $\begin{array}{l}0.31 \\
0.09 \\
0.18\end{array}$ & $\begin{array}{l}0.38 \\
0.15 \\
0.20\end{array}$ \\
\hline ポリウレタン & $\begin{array}{l}- \\
15 \\
15\end{array}$ & $\frac{-}{30}$ & $\begin{array}{r}400 \\
124 \\
41 \\
\end{array}$ & $\begin{array}{r}30 \\
80 \\
120 \\
\end{array}$ & $\begin{array}{r}24 \\
8 \\
160 \\
\end{array}$ & $\begin{array}{r}N^{*} \\
88 \\
88 \\
\end{array}$ & $\begin{array}{l}10 \\
64 \\
56 \\
\end{array}$ & $\begin{array}{l}0.32 \\
0.12 \\
0.20\end{array}$ & $\begin{array}{l}0.37 \\
0.18 \\
0.25\end{array}$ \\
\hline $\begin{array}{c}\text { 焼 結 含 油 軸 受 } \\
\text { (青銅系) }\end{array}$ & - & - & 117 & 160 & 400 & 720 & 136 & 0.24 & 0.20 \\
\hline $\begin{array}{c}\text { フェノール樹脂 } \\
\text { (木粉入り }\end{array}$ & 15 & - & $17 \sim 40$ & $>640$ & 720 & 925 & 280 & 0.16 & 0.26 \\
\hline $4 \mathrm{~F}$ & - & 25 & 10 & 160 & 210 & 256 & 184 & 0.08 & 0.16 \\
\hline
\end{tabular}

* $N=$ 使用不可 
の効果は顕著である。ガラスファイバを添加すると材料 の強度は増加するが，摩擦面では軸を傷つけたり研摩作 用があるため摩擦熱の発生が多く，そのためかえって摩 耗係数も多くなるし， $P V$ 值も期待するほど大きくなら ない。また摩擦係数も大きい。ガラスファイバ，ガラス 粉末共に一般に合成樹脂に添加される場合が多いが， 軸受材料としてほ決して好ましいものではない。ガラス 以外でも $\mathrm{Fe}_{2} \mathrm{O}_{3}$ や $\mathrm{Cr}_{2} \mathrm{O}_{3}$ のように鋼軸よりかたい材料 が添加されると同様に摩擦熱が多い傾向にある。4 F の 添加勃果の大きい樹脂々表 5 のような強力で耐熱性のよ いものであって，軟化点の低いものに添加すると $4 \mathrm{~F}$ が 摩擦面に露出しにくいため効果が薄い。

2. 2. 2 アセタールに $4 \mathrm{~F}$ を添加したもの

デルリン $\mathrm{A} \mathrm{F}^{6)}$ はアセタール樹脂のホモポリマに $4 \mathrm{~F}$

表 6 デルリンA F とデルリン500の性質

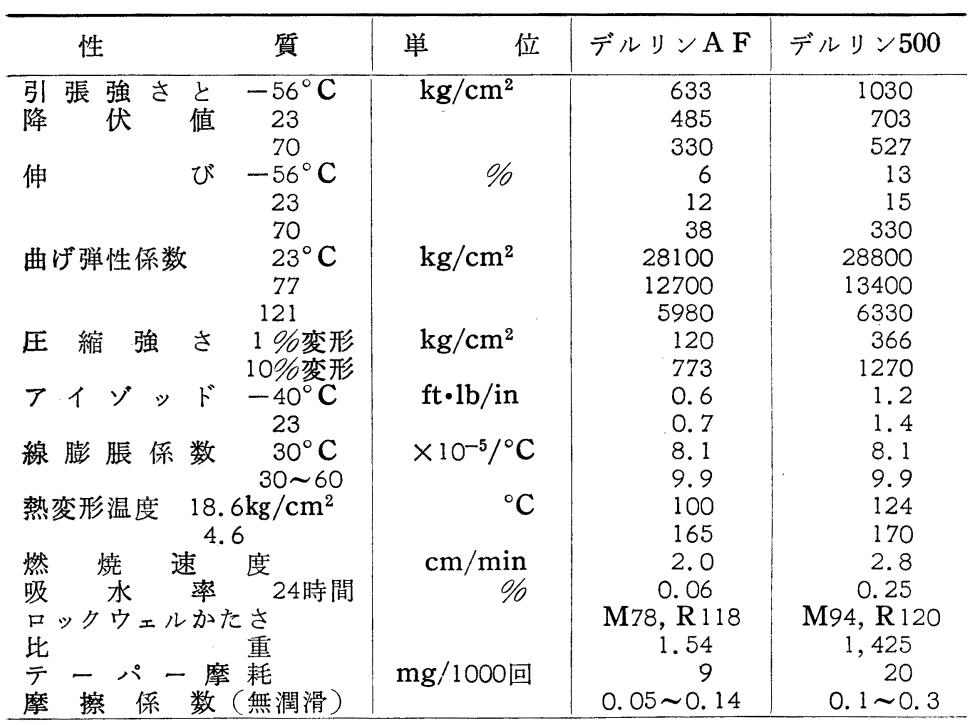

表 7 ポリカーボネートとフロナイトDの性質

\begin{tabular}{|c|c|c|c|}
\hline 性 & 質 & $\begin{array}{c}\text { ポリカーボネート } \\
\text { (パンライト) }\end{array}$ & $\begin{array}{c}\text { フロナイトD } \\
(F L D)\end{array}$ \\
\hline 張 強 & $\left(\mathrm{kg} / \mathrm{cm}^{2}\right)$ & 580 & 380 \\
\hline 伸 & $(\%)$ & 80 & 10 \\
\hline 引 張 弾 性 係 & $\left(\mathrm{kg} / \mathrm{cm}^{2}\right)$ & 14100 & 12300 \\
\hline ロックウエルかた & $\mathrm{M}$ & 76 & 57 \\
\hline ロックウェルかた & さ & 125 & 112 \\
\hline 衝 撃 強 & さ $(\mathrm{kg} \cdot \mathrm{cm} / \mathrm{cm})$ & 11.2 & 7.6 \\
\hline 縮 強 & さ $\quad\left(\mathrm{kg} / \mathrm{cm}^{2}\right)$ & 780 & 530 \\
\hline 圧 縮 弾 性 & $\left(\mathrm{kg} / \mathrm{cm}^{2}\right)$ & 16800 & 11000 \\
\hline 抗 折 & $\left(\mathrm{kg} / \mathrm{cm}^{2}\right)$ & 938 & 566 \\
\hline 曲 ゲ 弾 性 係 & 数 $\left(\mathrm{kg} / \mathrm{cm}^{3}\right)$ & 21000 & 13200 \\
\hline 耑クラック強 & $\left(\mathrm{kg} / \mathrm{cm}^{2}\right)$ & 186 & 136 \\
\hline 比 & 重 & 1.2 & $\begin{array}{r}1.35 \\
7.10^{-5}\end{array}$ \\
\hline 線 膨 張 係 & 数 $\left(\mathrm{cm} / \mathrm{cm}^{\circ} \mathrm{C}\right)$ & $\begin{array}{l}7.4 \times 10^{-5} \\
4.8 \times 10^{-4}\end{array}$ & $\begin{array}{l}7.5 \times 10^{-5} \\
4.8 \times 10^{-4}\end{array}$ \\
\hline 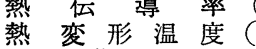 & $\left(18.6 \mathrm{~kg} / \mathrm{cm}^{2}\right)^{\circ} \mathrm{C}$ & 132 & 128 \\
\hline 耐 薬 品 & 性 & - & P C と略同様 \\
\hline
\end{tabular}

を添加したものである。表 6 にデルリン 500 とデルリンA $\mathrm{F}$ との性質を比較して示した。明らかに $4 \mathrm{~F}$ を添加した ものが性能が勝っている以上，今後は $4 \mathrm{~F}$ 入り軸受材が 従来のデルリンの地位にかわるものと考元る。

2. 2. 3 ポリカーボネートに $4 \mathrm{~F}$ を添加したもの ポリカーボネート（以下 P C と略記する）自身の軸受

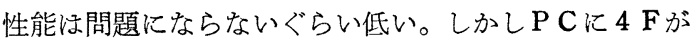

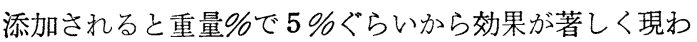
れ最高 $50 \%$ ぐらいまでは添加されて優秀なすべり性を示 す。表 5 にも示されてあるように限界 $P V$ 值がむしろ高 速になるにしたがってナイロンやフセタールよりも勝る 傾向にある。

フロナイト $\mathrm{D}^{7)}$ は P C と $4 \mathrm{~F}$ ととの他の添加材とより

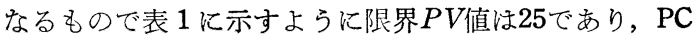
と $4 \mathrm{~F}$ の 2 元系よりも高性能であ る。フロナイト D は P C の耐衝撃 性, 耐クリープ性を利用している ため, 概してナイロンと $4 \mathrm{~F}$ ，アセ タールと $4 \mathrm{~F} の 2$ 元系およびその 他の添加材を加えたものよりも性 能は優っている。材料の圧縮試験 ではひずみ $3 \%$ (圧縮応力 $260 \mathrm{~kg} /$ $\left.\mathrm{cm}^{2}\right)$ まで法瞬問回復してフック の法則に従う。表7 はポリカーボ ネート (パンライト)とフロナイ トDとの性質を示したもので，4 Fその他を加えるため強さその他 がPCのみの材質よりも低下して いる。

\section{3 フェノール樹脂}

最も古い歴史を有するだけに実 績もあり，優秀な軸受材料であ る。熱硬化性ということが他の熱 可塑性のものに比較して強味であ り，信頼性を一応確保している。 性能を本当に発揮し得るのは, 油 潤滑よりもむしろ水潤滑である。 膨潤という現象汸あるが，機械的 強度任大き, 酎摩耗性も優秀で 耐熱性もよいので合成樹脂軸受と してはまず選択の第 1 に置かれる べきものである。表 $8,9,10^{8)}$ に種類と用途ならびに各種性質を 示す。この種フェノール樹脂軸受 メーカは多い。 
表 8 フェノール樹脂軸受の種類と用途ならびに諸性質

\begin{tabular}{|c|c|c|c|c|c|c|}
\hline 項 目 材質名称 & レッド & ブラック & ス タ & ハイテム & セルブ & $3 \mathrm{~A}$ \\
\hline 用 & $\begin{array}{l}\text { 軸受, 歯車, 摺 } \\
\text { 動面, ライナ, } \\
\text { ピストンリン } \\
ク ゙, \text { 口ーラ, 絶 } \\
\text { 縁材料他 }\end{array}$ & $\begin{array}{l}\text { 軸受, ブレーキ } \\
\text { ライニング，他 }\end{array}$ & $\begin{array}{l}\text { 軸受，（特に耐 } \\
\text { 摩性および高 } \\
\text { 負荷性能を要す } \\
\text { るもの）他 }\end{array}$ & 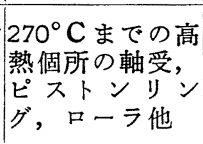 & \begin{tabular}{|l} 
自己潤滑性 \\
軸受
\end{tabular} & $\begin{array}{l}\text { 湿潤による寸法 } \\
\text { 変化をきらう精 } \\
\text { 密軸受, ビスト } \\
\text { リリング他 }\end{array}$ \\
\hline & 1.38 & 1.39 & 1.41 & 1.70 & 1.57 & 1.70 \\
\hline かた さ BHN & $37 \sim 39$ & $36 \sim 39$ & $36 \sim 39$ & $35 \sim 39$ & $32 \sim 37$ & $32 \sim 37$ \\
\hline 抗 圧 $\mathrm{kg} / \mathrm{mm}^{2} \perp$ & 30 & 33 & 31 & 29 & 23 & 30 \\
\hline th to $100 / /$ & 24 & 27 & 24 & 23 & 15 & 24 \\
\hline 折 $\mathrm{kg} / \mathrm{mm}^{2} \underline{1}$ & 13 & 14 & 11 & 7 & 5 & 8 \\
\hline 街軗值 & 9 & 11 & 9 & 5 & 6 & 7 \\
\hline 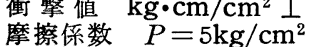 & 41 & 45 & 40 & 25 & 14 & 27 \\
\hline $\begin{array}{l}V=3 \mathrm{~m} / \mathrm{s} \\
\text { 水 潤 }\end{array}$ & 0.017 & 0.025 & 0.008 & 0.017 & 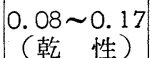 & 0.016 \\
\hline 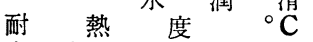 & 140 & 170 & 150 & 350 & 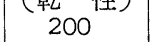 & 180 \\
\hline 常温清水中における & 2.0 & 2.0 & 2.0 & 0.5 & 0.5 & 0.5 \\
\hline 膨 潤 率 \% /I & 0.3 & 0.3 & 0.3 & 0.15 & 0.15 & 0.15 \\
\hline 摩耗率 & 42 & 30 & 12 & 41 & 46 & 48 \\
\hline
\end{tabular}

熱伝導度 $4 \sim 7 \times 10^{-4} \mathrm{cal} / \mathrm{cm}^{2} \cdot \mathrm{s} \cdot{ }^{\circ} \mathrm{C} \cdot \mathrm{cm}$, 耐電圧 $5 \sim 8 \times 10^{3} \mathrm{~V} / \mathrm{mm}$, 耐水耐酸耐アルカリ耐油性を有する

摩耗率は $P=170 \mathrm{~kg} / \mathrm{cm}^{2}, V=1.3 \mathrm{~m} / \mathrm{s}$ においてバビットメタルを 100 とした比較值で砲金は76

表 9 フェノール樹脂軸受材料

\begin{tabular}{|c|c|c|c|c|c|}
\hline \multirow{2}{*}{ 種 } & \multirow{2}{*}{ 色 } & 主 & 成 & 分 & \multirow{2}{*}{ 特 長 と 用 途 } \\
\hline & & $\begin{array}{l}\text { フェノー } \\
\text { ル樹脂 }\end{array}$ & 基 材 & 添加物 & \\
\hline $\begin{array}{l}\$ 250 \\
\$ 125\end{array}$ & 褐 色 & $\bigcirc$ & 布細片 & - & \multirow{6}{*}{ 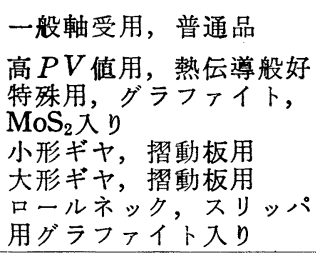 } \\
\hline $11-02$ & 薄褐色 & 0 & 布細片 & 0 & \\
\hline$\prime \prime-03$ & 黒 色 & 0 & 布細片 & 0 & \\
\hline$\prime \prime-04$ & 色 & 0 & 太糸布 & - & \\
\hline$\prime \prime-05$ & 褐 色 & 0 & 細采布 & - & \\
\hline$\prime \prime-06$ & 黒 色 & $\bigcirc$ & 太糸布 & $\bigcirc$ & \\
\hline
\end{tabular}

表10フェノール樹脂軸受材の諸性質

\begin{tabular}{|c|c|c|}
\hline 項 & $\begin{array}{l}\# 250-01.02 .03 \\
\# 425-01.02\end{array}$ & $\begin{array}{l}\# 250-04.05 .06 \\
\# 425-04.06\end{array}$ \\
\hline 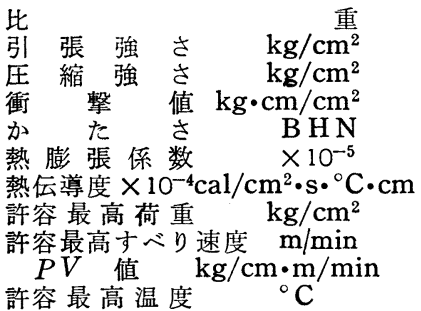 & $\begin{array}{c}1.3 \sim 1.4 \\
600 \sim 800 \\
1500 \sim 2000 \\
10 \sim 20 \\
30 \sim 40 \\
1 \sim 2 \\
4 \sim 7 \\
100 \\
900 \\
1000 \\
100\end{array}$ & $\begin{array}{c}1.3 \sim 1.4 \\
700 \sim 1050 \\
2000 \sim 3000 \\
30 \sim 60 \\
30 \sim 40 \\
1.5 \sim 2.5 \\
4 \sim 7 \\
150 \\
600 \\
1500 \\
100\end{array}$ \\
\hline
\end{tabular}

合などによって新材料は生まれる し，軸受としての構成，製作，使 用法などの改良によって新用途の 開発や性能向上が図られつつあ る。現在すでに新材料として登場 しているポリスルホン(P S), ポ リフェニンンオキサイド(PPO), ポリイミド（P I）などはその耐 熱性, 耐クリープ性により, 従来 のものよりもさらに性能の優れた 軸受材料となることが予約されて いる。P S と P P O はとの性質が 非常によく似ている。熱変形温度 $\left(18.6 \mathrm{~kg} / \mathrm{cm}^{2}\right.$ における) はP S が $174^{\circ} \mathrm{C}, \mathrm{P} \mathrm{PO} 190^{\circ} \mathrm{C}$ であ り，A S TM試験法 D-674 によ るクリープ強度は図 1 に示すよう に共にほぼ同じであって，P Cよ りも断然強い。それだけに摩擦面 に扮ける軟化流動倿対しても抵抗 が強く, 大きい $P V$ 值も期待でき る。PSやPPO自身の軸受性能涊必 ずしも満足すべきものではない。 軟化流動する温度が高くて子摩擦熱発生量が多いとやは り摩耗も早い。しかしこれらに各種添加材を加えて性能 を改良することができる。表 5 と同一の手法で $4 \mathrm{~F}$ を添 加すると性能は飛躍的に向上するのもその一例である。

\section{4 その他の合成樹脂}

合成樹脂の開発進歩は目覚ましいものがあり，軸受性 能も年々向上している。また従来古くより知られている ものでも特殊な添加材, 特殊な合成方法, 他種同志の共 
表11活筆者の実験による乾燥摩擦比較值である。フロナ イト D前述のごとく P C を主要材とするもの，フロナ イト F は P S を主材，フロナイトHはP P Oを主材とす るものである。このようにして高性能になれば，これを

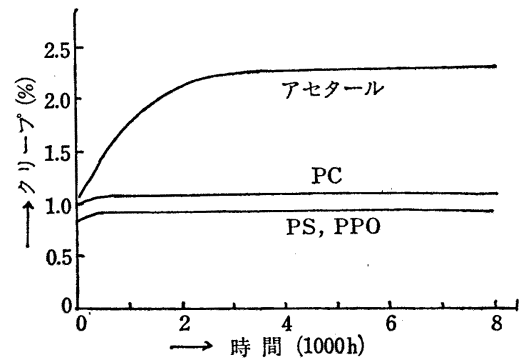

図 1 グリープ比較図, $2^{r} \mathrm{C}$, 引張り応力 $210 \mathrm{~kg} / \mathrm{cm}^{2}$

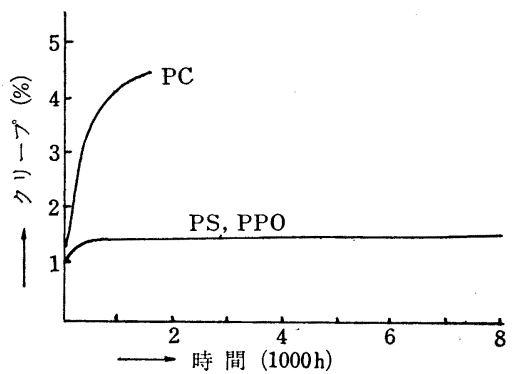

図 2 グリープ比較図, $100^{\circ} \mathrm{C}$, 引張り応力 $210 \mathrm{~kg} / \mathrm{cm}^{2}$

表11 各種材料の比較最高荷重

\begin{tabular}{|c|c|c|}
\hline 材 & 荷 重 $\left(\mathrm{kg} / \mathrm{cm}^{2}\right)$ & 験＼cjkstart法 \\
\hline 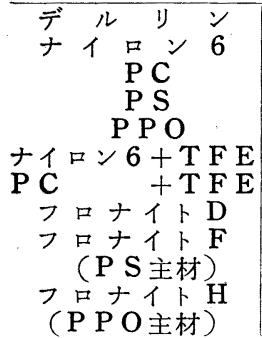 & $\begin{array}{c}2 \sim 7 \\
1 \sim 5 \\
0.5 \sim 2 \\
2 \sim 5 \\
2 \sim 5 \\
7 \sim 15 \\
10 \sim 15 \\
20 \sim 30 \\
25 \sim 35\end{array}$ & $\begin{array}{l}\text { すべり速度 } \\
1 \mathrm{~m} / \mathrm{s}(1000 \\
\text { r.p.m) で100時 } \\
\text { 間以内に摩耗あ } \\
\text { るいは軟化流動 } \\
\text { しない荷重を求 } \\
\text { める。 } \\
\text { 摩耗は } 0.1 \mathrm{~mm} \\
\text { を限度とする。 }\end{array}$ \\
\hline
\end{tabular}

鋼材裏金に薄くライニングするなどの使用法によってき わめて高性能完全無給油すべり軸受となることが期待さ れる。

ポリイミド成形材9)の熱変形温度はA S T M 試験法 $\mathrm{D}$-648による荷重 $18.6 \mathrm{~kg} / \mathrm{cm}^{2}$ で $240^{\circ} \mathrm{C}$ 以上であり, 窒 素中の摩擦試験では $P V$ 值として $35 \mathrm{~kg} / \mathrm{cm}^{2} \mathrm{~m} / \mathrm{s}$ が得られ ている。

\section{3.ゴム軸受}

ゴムは水に対する摩擦が少なく，砂や異物が入っても 埋めこむか外に押し出して軸をきずつけない。そのため 水潤滑軸受として攪汼機洗浄機, プロペラ軸, 方向舵, 水ポンプなどの他砂利の入るドレッジャをはじめとする 土木, 農業の諸機械に用いられている。ゴム軸受はモ一 ルド形，セグメント形および総ゴム形の 3 種に大別され る。モールド形活金型を用いて金属製円筒の内側にゴム を直接接着したもの，セグメント形法部分軸受の形式に したもの，総ゴム式は小形の縦形軸受として水ポンプに 用いられる。以前は天然ゴムを用いたが最近はブタジェ ンアクリロニトリルの共重合体を用いる。これは油にも 強いので各種化学液体用処理機械の軸受にも使用され る。最大荷重は $2 \sim 3.5 \mathrm{~kg} / \mathrm{cm}^{2}$ ，すべり速度は運転温度 が $65^{\circ} \mathrm{C}$ 以下に保たれるならば $50 \mathrm{~m} / \mathrm{s}$ ぐらいまで大きく できる。大形軸受で治制給水する必要がある。軸材質 は耐食性の良いものでなければならない。砲金，弁用青 銅，モネル，ステンレス，炭素鋼にクロームメッキして もよい。

\section{4. 黒鉛軸受}

自己潤滑性が良好であることの特長を活用して瀻維， 食品, 薬品関係の機械器具の軸受, 自己潤滑性之高温度 ( $450^{\circ} \mathrm{C}$ ぐらいまで) で安定であるため回転䉆炬，ボイ ラ，ジェットェンジンなどの高温軸受としては他の追随 を許さない。をた黒鉛の耐食性を利用してガンリンケ ロシン, 海水, 酸, アルカリなどを扱う器具機械ポンプ の軸受としても実用されている。黒鉛を焼結する際のピ

表12 黒 鉛 軸受用材質

\begin{tabular}{|c|c|c|c|c|c|c|c|}
\hline & \multirow{2}{*}{ 黒鉛のみ } & \multirow{2}{*}{$\begin{array}{l}\text { 合成樹脂 } \\
\text { 含 浸 材 }\end{array}$} & \multicolumn{3}{|c|}{ 金 属 含 浸 材 } & \multirow{2}{*}{$\begin{array}{l}\text { 表面処理し } \\
\text { た電気黑鉛 }\end{array}$} & \multirow{2}{*}{$\begin{array}{c}\text { セラミック入り } \\
\text { ガラス入り }\end{array}$} \\
\hline & & & $\mathrm{WJ} *, \mathrm{Cu}-\mathrm{Pb}$ & $\mathrm{Cu}$ & $\mathrm{Ag}$ & & \\
\hline 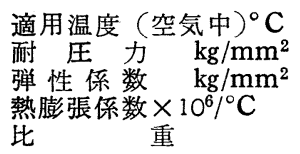 & $\begin{array}{c}200 \sim 400 \\
11.2 \sim 12.6 \\
910 \sim 1120 \\
2.5 \sim 4.5 \\
1.6 \sim 1.7\end{array}$ & $\begin{array}{c}200 \sim 320 \\
18 \sim 26.6 \\
1330 \sim 2170 \\
4 \sim 6 \\
1.8\end{array}$ & $\begin{array}{c}200 \sim 320 \\
24 \sim 28 \\
1680 \sim 3080 \\
4.5 \sim 6.0 \\
2.5 \sim 2.8\end{array}$ & $\begin{array}{l}370 \sim 500 \\
21 \sim 28 \\
840 \sim 2100 \\
4.5 \sim 6.0 \\
2.4 \sim 2.9\end{array}$ & $\begin{array}{l}370 \sim 500 \\
21 \sim 25 \\
840 \sim 1260 \\
4 \sim 6 \\
2.3 \sim 3.1\end{array}$ & $\begin{array}{l}500 \sim 650 \\
2.5 \sim 16 \\
490 \sim 140 \\
4.0 \sim 7.5 \\
1.7 \sim 1.9\end{array}$ & $\begin{array}{c}550 \sim 670 \\
7 \sim 19 \\
1150 \sim 1680 \\
4.0 \sim 6.5 \\
1.7 \sim 2.1\end{array}$ \\
\hline
\end{tabular}

* $\mathrm{W} \mathrm{J}=$ ホワイトメタル 
ッチその他の配合，圧力によって有孔率を加減できるの で，これに油や合成樹脂，金属その他を含浸させて耐摩 耗性やすべり性を改良する。表 $12^{10)}$ 亿各種の黑鉛軸受材 質を示す。黑鉛のみの材質の適用荷重䏡 $2 \mathrm{~kg} / \mathrm{cm}^{2}$ 以下が よいが，含浸材は最大 $50 \mathrm{~kg} / \mathrm{cm}^{2}$ まで使用できる。 $P V$ 值 以乾燥摩擦で $3 \sim 5 \mathrm{~kg} / \mathrm{cm}^{2} \cdot \mathrm{m} / \mathrm{s}$ である。潤滑材や液体 を用いて $P V$ 值を大きくできる。軸はH R C 50以上の硬 質で耐食性のよいものを選び，仕上程度を $10 \mathrm{RM} \mathrm{S}$ 以上 とするのがよい。クロームメッキもよいし，各種カーバ イドが歓迎される。

\section{5. 軸受性能}

\section{5. $1 P V$ 值}

乾燥摩擦用軸受としての合成樹脂の限界 $P V$ 值を求め る方法としては通常 2 種類ある。第 1 の方法 $\mathrm{A}$ 以軸受合 金でも利用せられるもので，軸受材料が摩擦面で急激な 温度上昇や摩耗を起こし初める時の $P$ と $V$ との関係を求 めるもの，第 2 の方法 $\mathrm{B}$ 泣一定の摩耗量を生ずるための $P$ と $V$ との関係を知るものである。方法A を一定にしておき，荷重を一定時間ごとに増加してゆき 温度や摩耗量が急に增加する限界点を求め, その時の $P$ を知る。方法 $B$ はたとえば 1000 時間で $0.1 \mathrm{~mm}$ 摩耗する 場合の $P$ と $V$ を求めるのであるから長時間を要し，方法 $\mathrm{A} の P V$ 值よりも小さくなるがむしろ実用的でもある。 方法 $\mathrm{B}$ 法摩耗係数 $K$ が既知であればそれより $P$ と $V$ を知 ることができるが，むしろ $K$ を求めるために $P$ と $V$ との 関係を知る方法である。表 2 と表 5 亿A法と B 法の限界 $P V$ 值を示してある。通常用いる $P V$ 值法 $\mathrm{A}$ 法が多い。 摩擦面の温度 $T$ 认

$$
T=\frac{1}{K_{1}} \cdot \frac{1}{K_{2}} \cdot \mu \cdot P \cdot V
$$

で示される $K_{1}$ ほ軸およびハウジングを含む機械の熱放 散度, $K_{2}$ 注軸受自体の熱放散度， $\mu$ 注摩擦係数，P江 荷重，Vはすべり速度である。

$P V$ 值が大きくなるためにはまず $T$ が大きいこと， $K_{1}$ と $K_{2}$ が大きいとと， $\mu$ の小さいことが必要である。 摩擦面の温度が高くなっても軟化溶融流動しない耐熱性 のよい材料ほどTは大きく，それだけ $P V$ 值は大きなり やすい。

表11にその例を示した。しかし 熱性が良くても $P V$ 值惊小さくならざるを得ない。表 5 のように $4 \mathrm{~F}$ 添加して $\mu$ を小さするとその差が判然と する。つまり合成樹脂でほ $T$ が大きく， $\mu$ の小さい材料 が好ましいことになる。また $K_{2}$ を大きくするためには 金属を台金としてこれに薄肉にライニングすることも良
い方法であり，フロンメタル（およびDUべャリング） ほこの一例である。さらに $K_{1}$ の大きい条件下で使用す ることも $P V$ を大きくすることになる。すなわち $K_{1}$ の 異なる条件下では $P V$ 值も異なる值を有することになる たとえば冷凍機や洗濯機に用いる場合と加熱器や扇風機 に用いるもので法異なる $P V$ 值で設計されてもよい。同 じ機械でも冬ほ夏よりも大きい $P V$ 值を適用し得る。高 温度の環境で嫦温の場合よりも $P V$ 值は小さくなる。 表 3 でその例を示した。油や水を潤滑戍に用いると $K_{1}$ が大きくなるし $\mu$ も小さくなる。表 4 にとの例を示し た。

\section{2 耐摩耗性}

合成樹脂の耐摩耗性法実験值か実用結果より判断する のがよい。最近のようにその種類が多くなると摩耗とい う現象も各合成樹脂で变化するので非常に複雑性を増し てきた。金属の摩耗で注化学摩耗, 機械摩耗, 溶融摩耗 の 3 種の過程があるが合成樹脂で汸化学的なじみ面の形 成といらことほほとえど考兄られないので化学摩耗がな い。したがって摩擦開始とともに機械摩耗で終始する。 そのため材質がかたい，強い，耐熱性ということは耐摩 耗性の条件となる。機械摩耗のみが行なわれるとするな らばその摩耗量注 $P$ と $V$ と時間に比例すると考元られ る。もちろえ乾燥摩擦の場合であるが，この時の摩耗量 をWとすると

$$
W=K P V H
$$

で示される。 $K$ 泳摩毛係数, $P$ ほ荷重, $V$ はすべり速度, Hほ摩擦時間である。しかしこの式が全部の合成樹脂に あてはまるものではない。たしかに $4 \mathrm{~F}$ のうにせえ断 強さが小さいとか, 粘性流動しやすい材質ではこの式が 完全に適用できるが，強力なエンジニヤリングプラスチ ックになるとひずみと応力の関係が直線となる範囲すな わち完全にフックの法則に従うような弾性範囲の応力を 軸受荷重とする摩擦条件で注全然摩耗しない現象が見ら れる。また(1)式のように摩擦面の温度上昇による機械的 強さ，かたさの变化任当然Wに影響があるから $\mu P V$ と して摩耗を左右する法ずである。またP P Oおよびポリ イミドのように摩擦面が酸化するとそのために金属のよ うに化学的なじみ面の形成や酸化摩耗現象もある。しか し一応(2)式のようにして $K$ を求めると表 2 , 表 5 のよう になる。

(2)式のW法变化で示す。

いま $P=7 \mathrm{~kg} / \mathrm{cm}^{2}, V=30.5 \mathrm{~m} / \mathrm{min} て ゙ W=0.05 \mathrm{~mm}$ 摩 耗するに要した時間が 500 時間であると(2)式より

$$
K=4.7 \times 10^{-10} \mathrm{~cm}^{2} \cdot \min / \mathrm{kg} \cdot \mathrm{h}
$$

となり,これを in-ft 系単位で示すと 
$K=4.0 \times 10^{-10} \mathrm{in}^{3} \cdot \min / \mathrm{ft} \cdot \mathrm{Lb} \cdot \mathrm{h}$

となる。

\section{3 なじみ性}

ゴム軸受は弾性があるし，軸受すきまも多くして水潤 滑で使用するので，仕上寸法が適当であればまず焼きつ くことはない。黒鉛軸受は相手材の摩擦面に黒鉛が移っ て黒鉛同志の摩擦現象となり，黒鉛自体が潤滑材であ り，高融点を有し熱伝導性も良いので焼きつくというこ とはない。しかし相手に移ることは摩耗である。黒鉛に 合成樹脂あるいほ金属を含浸させたものほ耐摩耗性は向 上するが，逆に焼きつき現象が発生する。

合成樹脂を完全無給油で使用する場合，大きい熱膨張 係数と低い熱伝導性は摩擦開始後短時間で焼きつきを起 こしゃすい。その大部分は摩耗熱によってすきまが減少 し，ますます摩擦が強くなって軟化流動焼きつき現象を 招来する。したがって合成樹脂ではすきまを多くとると か，特別になじませるという手段が必要となる。軟かい 材質, 低融点のものならば部分的に摩耗するか, 塑性変 形して直ちになじるやすいが，ナイロン，PCその他の 強力で融点も高い材質では簡単になじみ面が得られな い。合成樹脂のなじみ現象は前述のように機械的になじ むことであるから，上手に平滑ななじみ面を作るように することが好ましい。そのため摩擦開始前に潤滑油を軽 く塗布することは意味がある。軸表面の凹凸は摩擦開始 の瞬間に合成樹脂を削り，その摩耗粉は凹部を埋める か, あるいは軸表面に薄い膜（部分的でも）となって付 着する。もしこのようになると次の瞬間から合成樹脂同 志の摩擦に変わってくる。これが次第に熱を多く発生す る原因となる。この時油膜が最初から存在すると削られ ることもないし合成樹脂同志の摩擦もなくて機械的なじ

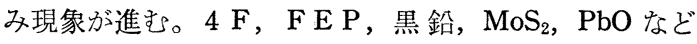
は最初から完全乾燥摩擦で摩擦して相手面に移り, 次に これら同志の摩擦となってもその後の悪影響はない。こ のように同一材質同志の摩擦が許されるのは $4 \mathrm{~F}$ ，黒鉛 などの固体潤滑材の特権である。 $4 \mathrm{~F}$ と F E P 以外の合 成樹脂は最初の摩擦で相手軸表面に自身の材質を移して はならない。以上の理由で油をあらかじめ塗布すること は良好ななじみ性を与えるために好ましいことである。 そして精度保持にも効果がある。しかし最初油を塗布し てもその後は完全無給油で摩擦すると，ついには油は枯 渴して乾燥摩擦に移行する。このような状態になっても そのまま変化せずに同一の摩擦状況を維持できるような
荷重やすべり速度をその材質に適用するのが正しいこと である。4 Fを添加した材質(表 5 , 表11を参照)の性能 向上はこの荷重やすべり速度が大きくなるためである。

\section{6. 用 途}

合成樹脂軸受, ゴム軸受, 黒鉛軸受ほいずれも潤滑油が なくしては満足な運転を示さない金属軸受の使用できな いところでその特性を発揮し得るが，油膜潤滑軸受とし ても油を污さない，軸を傷めないなどの理由で金属軸受 の領域を侵しつつある。無給油軸受としては合成樹脂と 黒鉛，水潤滑軸受としてほフェノール樹脂，ゴム，高温 軸受（潤滑油の使用できない高温）としては $4 \mathrm{~F}$ ，黒

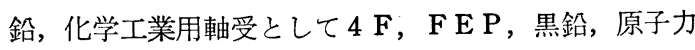
関係諸機械の軸受特に高温用として黒鉛, セラミック $\left(\mathrm{Al}_{2} \mathrm{O}_{3}\right.$ が多い) が用いられている。無給油軸受として の合成樹脂の性能は最大 $P V$ 值で $30 \mathrm{~kg} / \mathrm{cm}^{2} \cdot \mathrm{m} / \mathrm{s}$ 位であ り, 元来低融点, 熱伝導度の不良, 熱膨張の大きいこと がその用途拉よび使用条件を大きく制約している。今後 の課題としては鋼材を裏金として補強し, 薄肉ライニン グした形式の軸受としてその用途を拡大しなければなら ないだろう。

しかし現実には現在の合成樹脂の性能程度でもその用 途は実に多いし，それだけに合成樹脂同志でも互いに競 争している。たとえば瀻維機械ではフェノール樹脂, ナ イロン, アセタール, ポリカーボネート, フロンメタル などが各社各工場でまったく同一種の軸受に使用され， かつ試験されている。同一性能ならば安価な方が勝利を 得るのであるからいずれ適所適材に落ちつくが，各種材 質はそれぞれの特性が活用できるような用途に向けられ るべきである。

\section{引用文献その他}

1）日東フロロケミカル(株)の型録.

2）ダイキン工業(株)の型録.

3）日本バイメタル(株の商品名.

4) 大同メタル工業(株の商品名.

5) MACHINE DERIGN JUNE 23, 1966, 158.

6) 昭和ネオプ!ン(株の商品名.

7）日本バイメタル(株の商品名.

8）スターライト工業(株)，日本オイレス工業(侏の型 録.

9）佐藤；工業材料，第 13 巻第 10 号.

10) ROBERT W.CARSON ; PRODUCT ENG. JUNE 41965. 